\title{
DEVELOPMENT OF CULTURE INNOVATION CAPABILITY OF BALI GOVERNMENT TO WELCOME GLOBAL MARKETS OF TOURISM
}

\author{
Gede Wirata $^{1}$, , Ida Ayu Putu Sri Widnyani \\ 1 Universitas Ngurah Rai \\ ${ }^{2}$ Universitas Ngurah Rai
}

\begin{abstract}
Abstrak
The forces of globalization have been able to shift patterns and lifestyle of people of the world, no exception in the tourism industry. The process of globalization has changed the form and structure of the tourism industry. The phenomenon requires countries in the world to evolve in a new system of government which is adaptive, innovative and sensitive to changes. Bureaucratic reform in Indonesian has been proceeding for many years. However, persisting problems concerning bureaucracy have yet to be resolved. This snag may arise due to the lack of the creativity and innovation culture within government bureaucracy. Therefore, bureaucratic reform should be directed more to innovation culture and programs including tourism sector in order to enhance the bureaucracy's innovation capability.
\end{abstract}

\section{Keywords:}

Culture Inovation,

Government

Bureaucracy, Global

Tourism.

\section{INTRODUCTION}

Globalization has penetrated almost every aspect of the human life. This phenomenon is characterized by global telecommunications systems, global transportation, global culture, the emergence of global products, global markets and operating globally companies (multinational company). Consequently, the concept of a closed state (building block) commonly known a few decades ago can not be maintained anymore because the concept violates the free market paradigm and no longer recognize geographical boundaries. Globalization has created interdependence among nations and created the same trend of patterns and lifestyles and societies around the world (Salam, 2002: 5).

For the tourism industry, the globalization process has led to a new trend in the shape and structure of the tourism industry and the Fordian of Tourism, characterizing its mass tourism product into New Age of Tourism (NAT). This change is not only a fundamental change in the character of consumers, producers, and management of the international tourism industry, but also the rapid changes and information technology that supports it. The tourism industry will be confronted with mature tourist characters, not the masses and travel to seek spiritual sources of life, no longer just material and physical pleasures.

This will affect the creation of tourism products that have appeal from the perspective of consumers. At the management level, a change of orientation toward selling products that meet market demand, and marketing still leads to individual consumers, and the use of mass branding to branding diversity, and price competition on quality competition. On the technology side there is a new demand for integrated information technology, more friendly, rapid technology diffusion, systemic, and moving towards global networking. The changing shape and structure of the tourism industry as a result and the flow of globalization demands every country to increase its competitiveness in the global tourism business scene.

The impact of globalization in Indonesia requires changes in the system of government to be able to adapt to the current global era. The demands for reform in the bureaucracy are inevitable. The bureaucracy must be transformed into an open system that is oriented towards public service. Bureaucrats are required to dare to develop creativity and innovation in the delivery of public services. These great changes will propel him to evolve and the government that has local orientation becomes a 
government that has global cosmolit orientation (Kertajaya, 2000: xvi). They open themselves to the entry of global resources and seek to gain these resources for the improvement of people's quality of life.

There are quite a lot of problems in the government bureaucracy that became public issues in Indonesia today. Some of these problems are caused by high abuse of authority and irregularities, poor performance of apparatus resources, inadequate institutional (organizational) system and governmental management, low civil servant welfare, and many laws and regulations that are inconsistent with the development of conditions and development demands.

These public issues are basically not new issues in the Indonesian government bureaucracy. This can be demonstrated through a review of various documents of national development plans, since the First Five Year Development Plan (Repelita) I of 1969 / 70-1973 / 74 up to the 2004-2009 RPJMN, 20092014 and even 2014-2019. Based on the study of the various documents, it is found that most of the issues in the current bureaucracy are classical issues that have emerged long before even Repelita I was rolled out.

The most interesting thing here is the existence of such public issues which have from time to time persisted and seem very difficult to resolve. Since 1966 until now, the government has implemented various programs and activities aimed at bureaucratic reform. Public expenditure that has been absorbed for the benefit of bureaucratic reform is also not small. Thus the policy of bureaucratic reform in Indonesia is indeed worthy to be studied.

However, it is not easy to understand the phenomenon of bureaucratic reform in Indonesia. The experts of public administration in Indonesia also disagree in understanding the existing phenomenon. Some experts consider the main issue of bureaucratic reform in Indonesia is the issue of human resources, both regarding leadership commitments, as well as the quality and morality of civil servants in general. While some other experts more highlight the system as a determinant of the performance of bureaucratic reform. The government reform strategy is in fact also directed to make improvements to both aspects. However, the facts about the performance of bureaucratic reforms to the present time have not been satisfactory.

This phenomenon indicates the determinants of the performance of reforms that have not received the attention of experts and policy makers in the government bureaucracy. Caiden (1969) has already reminded the strong influence of these factors on the performance of reforms, as did Peters (2000) and Farazmand (2002). The factor is culture. Culture greatly influences the performance of reforms, since reforms are closely linked to the beliefs, values and attitudes adapted and developed in the bureaucracy (Shenkar, 2006).

One of the most important bureaucratic cultures for bureaucratic reform is the development of innovation in government agencies. Innovation is very important, because it allows the bureaucracy to function more dynamically and make improvements. This paper is intended to see bureaucratic reform in relation to the culture of innovation in the bureaucracy of the local government of Bali towards the global tourism market.

\section{MATERIALS AND METHODS}

This study is a literature study in which the data discussed is secondary data derived from documentation studies collected by researchers, especially about the development of cultural innovation skills bureaucracy Local Government of Bali to the global market.

\section{DISCUSSION}

\section{Innovation Development in Bureaucratic Culture in Indonesia}

In the last decade, the practice of innovation in the administration of government bureaucracy in Indonesia has been expressed in a number of literatures. Some areas that are often referred to as best practices of innovation include Gorontalo Province, Sragen Regency, and Jembrana Regency. Given the performance of these three areas, it is evident that innovation is indispensable for government bureaucracy in the reform process.

For the local government in general, the phenomenon of Gorontalo Province, Sragen Regency, and Jembrana Regency is a very valuable lesson. In these areas, the capacity of local governments to innovate in the regions appears to be positively correlated with community support for their respective local governments. The most obvious form of community support is the re-election of the Governor, Regent or Mayor for the second period of his / her leadership, and this is a reflection of the community's satisfaction with local governance. 
The phenomenon in these three areas could be a common thing if it happened in the days before the direct election system (PILKADA) was put into effect in 2005. But in the present, what happens to the three regions is part of learning for leaders in other areas, especially those wishing to retain their positions for two periods. This is because in the PILKADA mechanism there is considerable space for the community to determine the fate of the leadership of public officials in the regions

In these three areas, public support for local heads of subdistricts is enormous, indicated by the high percentage of people who choose them to return to regional leadership, which is above $80 \%$ of the total participants in PILKADA (Regional election). Election Results in Gorontalo Province, 81\% of the votes supported Fadel Muhamad to return to lead Gorotalo Province until 2011. While in Sragen regency, Untung Sarono Wiyono Sukarno, got $87.34 \%$ of the votes to return to office of Sragen Regent for the period of 2006-2011. While I Gede Winasa get public support to become Regent of Jembrana the second time, with the percentage of votes reached $88.56 \%$. All this shows that people have high confidence in the leaders, and put considerable hope for improving their lives in the next leadership.

It is undeniable that the success of these regional leaders in gaining public support and confidence is because the strategies and policies they developed during the first period of leadership have produced results that can be enjoyed by the community. The key to this performance is innovation. Through innovation they are able to significantly improve the performance of the region they lead. The success story of innovation of Gorontalo, Sragen and Jembrana has actually been put forward in various writings in journals, newspapers, and seminars. Along with that, innovation became a popular word on the tongue and ears of government organizers in Indonesia. In today's development, innovation is even believed to be a necessity for local governments. The rationale is that innovation has been proven to increase the effectiveness of regional government, which has been shown primarily by the three regions mentioned in this paper. Moreover, innovation is needed in facing the environmental conditions of local governments today. Since regional autonomy was introduced in 1999, local governments, in addition to having broad authority in managing local government, also have a great obligation to provide good services to their communities. In this context, innovation is needed so that the quality of services provided by the local government is closer to the real needs of the community.

Although awareness of the need for innovation in local governance seems to be getting stronger, but in reality not many local governments are currently implementing innovation in the process of governance. Of the total number of local governments in Indonesia is estimated to be no more than $5 \%$ that stands out in innovation. In general, local governments impose governance as a routine, business as usual. Various government efforts to encourage innovation in the bureaucracy through a variety of awards, also did not show much results as expected.

Innovation is thus not yet an important element of the bureaucratic culture of government. This also indicates that the current government bureaucracy has not been able to absorb and develop more advanced management values. The cause of the condition can be sought on the attachment of government bureaucracy values with the concept of weber. As stated Agus Dwiyanto (2006), that the low innovation of government bureaucracy due to bureaucratic structure that is very hierarchical, fragmented and rigid. However, this still requires further verification. This proof is necessary, because the facts show that the behavior of the government bureaucracy also does not reflect its conformity with Weber's bureaucratic values. The results of Agus Dwiyanto (2006) conducted in 2000 and Eko prasojo (2006) in 2005 revealed that non-compliance with procedures and weak supervision still characterize the government bureaucracy. Other than that, innovation is also still possible in weber's bureaucracy, although it centers on the top level of management in the bureaucracy.

\section{Development of Innovation Capacity of Government Bureaucracy in Indonesia}

What is the cause of this bureaucratic innovation of governmental phenomenon? Theoretically, this can be explained through the concept of "innovation capability" or innovation ability. According to Terziovski (2007), this innovative ability provides the potential for effective innovation. Thus, for the government bureaucracy innovation capabilities of each government institution is actually very instrumental in the creation of creativity and innovation that led to improving the performance of government bureaucracy.

Referring to Lawson and Samson's (2001) definition of innovation capability, the ability of government bureaucracy innovation is interpreted as the ability of government bureaucracy to transform sustainable knowledge and ideas into new forms of services, processes, and systems for the benefit of institutions and stakeholders. Moving on from this understanding, the ability of government bureaucracy innovation is not a stand-alone concept, but it deals with various aspects of management, leadership, and technical aspects such as strategic resource allocation, stakeholder understanding, and so on.

The number of factors that affect the ability of innovation of government bureaucracy affects in the ability of each government agency to innovate differently from one another. Therefore, these factors are 
very important to recognize, especially to build adequate strategies for improving the innovation capabilities of a government agency. Only, the introduction of these factors is not an easy job. Even in innovative institutions, few understand the factors influencing the success of innovation (Shenkar, 2006), the difficulties experienced by the government's bureaucracy in Indonesia.

According Terziovski (2007), the ability of an institution's innovation is determined by a number of factors which he calls the dimensions of innovation ability. The dimensions of innovation capability include: vision and strategy, basic competency attachment, information strengthening and organizational intelligence, market and customer orientation, creativity and idea management, organizational systems and structures, and technology management. In the practice of governing governance in Gorontalo, Parepare and Sragen, the various dimensions of the innovation capability also seem to clearly affect the success of innovations applied by the three regions.

a. Vision and strategy

Innovation is not only the main value in governance in Gorontalo Province, but at the same time placed as a destination. Innovation occupies a highly regarded position: Vision. With such innovation, the strategy is designed to generate innovation, such as through the inculcation of entrepreneurial values within the local government bureaucracy.

The pull of vision towards innovative behavior is also demonstrated by the Regional Government of Sragen and Jembrana Regencies. When public trust serves as the goal of local government, local government becomes innovative in an effort to increase public trust. In some ways the Sragen regency's strategy has similarities with Jembrana Regency through the provision of free health services for poor families and the implementation of One Stop Sevice (OSS) to improve the quality of local government services. It's just that, for the education sector Jembrana go further with the implementation of free education from elementary school level to advanced level.

b. Basic attachment of competence

There is a similar awareness to the local government of Gorontalo Province, Sragen Regency and Jembrana Regency about the importance of apparatus competence in achieving organizational goals. Various strategic steps to increase the competence of the apparatus are done by the three local governments aimed at improving the creativity of the apparatus so that it is more innovative in the provision of services and to improve the mastery of e-government.

In the Provincial Government of Gorontalo Province, the development of apparatus competence is done through sending the task of studying local government employees to various universities in Indonesia, such as UGM, UI, ITB, Unhas, Unhalu, Unair, Unibraw and STIA-LAN; skill-need training design, local performance benefits, special welfare for educators and education personnel, regional-based education with strengthening of local competencies, and performance appraisal of productivity-based employees. While Sragen regency, facilitate the district civil servants to master computer and English. As for Jembrana District, the development of apparatus competency is done through the assistance of education cost for teachers to continue to higher education level, cooperation with BPPT in software development training, and computer training for PNS class II.

c. Strengthening information and organizational intelligence

The smoothness and speed of information flow is critical to the success of an activity whose support processes are in many units / work units. In order for information to flow quickly and smoothly, the institution generally performs process transformation by basing on technological capability. It is implemented by Sragen regency that uses e-government to support information flow related to licensing. In such systems, technology facilitates information flowing between the Integrated Service Agency (BPT), all units, 20 sub-districts and 208 villages. Similar strategies are also developed in Jembrana District within the framework of One Stop Service.

d. Market and customer orientation

Customers of services generated by government agencies are the general public, and the main task of the government is to satisfy the public through these services. In this government-community relationship, the fulfillment of "community satisfaction" is a value that must be embedded in every soul of the government apparatus. To realize the strategy, Gorontalo Provincial Government instills entrepreneur spirit in bureaucracy. One of the effects of this new character, local governments finally able to see the market demand for corn which is then used as the main commodity of Gorontalo Province.

In addition, through this strategy, to improve the satisfaction of the local government should also always make performance improvements over the service. For this purpose, local governments must have adequate information about the satisfaction of the community for services provided by the local government, among others through customer satisfaction surveys as conducted by BPT Kabupaten Sragen every 6 months. 


\section{e. Management of ideas and creativity}

Innovation will not happen if there is no freedom to develop ideas and creativity. Sragen Regent provides management flexibility to BPT so that this institution can further develop more innovative management, which is shown, among others, through the installation of billboards and the replacement of BPT uniforms with civilian clothes. While in Gorontalo Province, innovation is not only facilitated through the opening of space for the emergence of creative ideas, even placed as the main focus of human resource management strategy. In this province, human resource management apparatus directed to the creation of entrepreneurial spirit that prioritizes innovation, teamwork, trustworthiness, prosperity, and speed.

f. System and organizational structure

System development in Sragen regency, Jembrana regency, and Gorontalo province is intended to support the development of new services (new service development). In Sragen regency, BPT is given full authority by the Bupati to manage the licensing service and account for its direct performance to the Bupati. With the authority it has, BPT then innovate in the management process through the development of e-government based network system. Use of information technology (IT) is further proven to improve the speed of licensing services Sragen regency.

In this system innovation and organizational structure, the strategy developed by Jembrana Regency has similarities with Sragen regency in terms of IT usage. Jembrana District, implements an egovernment based network for OSS implementation. In addition, Jembrana District develops egovernment for the benefit of wider local government management, which is integrated in Jimbarwana Network (Ji-Net).

In contrast to Sragen and Jembrana districts that use IT to strengthen their organizational systems and structures, innovation on organizational structure in Gorontalo Province emphasizes on institutional arrangement. In these provinces, institutions believed to be central to the management capacity of local governments, including finance, personnel and health, are established as bodies and are directly responsible to governors with functions directed to the success of innovative governance. This institutional change has not only affected the performance of local government innovation as a whole, the province is also awarded as the best province for the Achievement of Toward Financial Administration from the BPK in 2007.

g. Technology management

Technology becomes an integral part of local government innovation. In the case of the implementation of OSS in Sragen, the local government established a technology-based network capable of connecting between various institutions related to licensing up to the village level. To support the operationalization of this strategy, in every village in Sragen regency, 3 civil servants are assigned to have a special task to operate IT. While in Jembrana District, technology is used for various purposes of local government, especially for Mayan Office (Kantaya) and Local Government Information System (SIMDA) applications.

The innovation capability of business institutions and government agencies does not necessarily make it an innovative institution. According to Terziovski (2007), in order for the organization to be innovative, its innovative capability should be placed on three domains which include: sustainable development, e-commerce, and new product development. As for the capacity of government bureaucracy innovation-taking into account the experiences of Gorontalo Province, Jembrana District and Sragen Regency, the domains that are the driving force and amplifier of innovation are not much different from those mentioned by Terziovski, except for e-commerce which is less visible in bureaucratic government innovation. In this case, then emerged a very important new domain for bureaucratic government innovation: e-government.

a. Sustainable development

Until now, the environment has not become a domain that many government bureaucracies are paying attention to in developing their innovative capacity. This is actually very unfortunate, given the carrying capacity of the environment for life in almost all regions in Indonesia in a condition that concern. While this domain is very important for the sustainability of human life history, so the innovations directed by the domain will be of great value to both the current population and to those living in the future.

However, for the Sragen Government, sustainable development has become part of the goal of innovation in Sragen regency. Some of the policies set out related to this domain include: organic farming, bird shooting, prohibition of fishing with poison, and prohibition of nailing trees. Some of these policies are also equipped with punishment provisions, such as a fine of 100 million or 10 years in prison for fishing with poison and a fine of 50 million or 5 years in prison for a bird shooter. 
Attention to the environment is also shown by Jembrana District Government. This domain driven innovation embodies the marine water treatment policy into mineral water (known as Megumi) and the policy of processing waste into organic fertilizer.

b. E-government

E-government is a highly influential domain of government bureaucracy innovation, and acts as a driver as well as an enabler of innovation capacity. As drivers, e-government encourages better and faster quality of service in licensing, through re-evaluation of the various practices and services being carried out. Meanwhile, as an enabler, e-government supports the creation of new innovations in public service and public access to various services provided by the local government. In the case of OSS held by Sragen regency, e-government has made the district has an improved performance in investment.

While e-government support for ease of public access to various public services has been shown both by Sragen regency, Jembrana regency, and Gorontalo province. Communities in both districts are increasingly facilitated in various licensing services. Even in Jembrana District, e-government has enabled the community to access health facilities easily. The Province of Gorontalo, although relatively behind in the use of e-government when compared to Sragen and Jembrana, has also used e-government for various purposes, such as investment promotion, e-procurement, and personnel management information system (SIMPEG).

c. New product development

The authority currently owned by the local government has implications for the increasing number of services that the local government must provide for its people. Various strategies can be undertaken by local governments in the provision of such services, through the development of cooperation with other institutions, the creation of an organizational climate conducive to innovation, and strengthening networks within the local government bureaucracy. This has been demonstrated, among others, by the Jembrana regional government, which established cooperation with BPPT in the early stages of innovation strategy development. Similarly, the Province of Gorontalo which cooperates for the development of human resources apparatus with various universities, such as: UGM, UI, ITB, Unhas, Unhalu, Unair, Unibraw and STIA-LAN. Meanwhile, efforts to create favorable conditions for the development of creative and innovative ideas are also demonstrated by Gorontalo Province. In this provonsi, human resource management is designed to produce an entrepreneurial apparatus.

\section{Development of Innovation Capacity Local Bureaucracy of Bali Government Answering Global Tourism Market Demands}

The development of tourism in the past has resulted in considerable achievement, through the growth of foreign exchange gain and the improvement of the national economy. Nevertheless the overall achievement above is not achieved without "cost" either in terms of environment, socio-economic and cultural. Much data and information provide evidence of how successful the development of the tourism industry is associated with environmental degradation, marginalization of the weaker parties, the occurrence of leakage of foreign exchange generated. Institutional side, tourism built with growthoriented, top-down, and centralistic approach as happened during the past three decades proved to have created dependency between people and bureaucrats, in the sense of weakening people's ability to actualize their potential. The number of mortality rates of existing development projects. is a reflection of the weakness of the sustainability of the development project itself. The characteristics of such a development project include: a) Initiatives are usually initiated and centered in the form of formal plans, b) The process of programming is static and is dominated by expert or technocratic opinion, c) The technology used is usually "scientific" and is sourced from the outside, d) Institutional mechanisms are top down, e) Rapid growth, however, is, f) The focus of attention is on how to project on time in accordance with existing budget policies.

All these traits lead to weakness, the inability of the project to create seff generation of input conditions and endanger the sustainability of the development project itself. (Sunaryo, 1993: 4)

Many cases can be found that tourism activities in the past is a government activity (officials), so if the official concerned moved (replaced) usually the activity was not forwarded again. In one of the districts, for example, the previous regent was very diligent in promoting the tirta (water) tour, namely rafting. Several boats have been held and rafting activities in the river have become a tourist attraction, When the regent was replaced and the new regent was not happy with white water rafting, then the activity was automatically stopped.

Learning and past mistakes to deal with the increasingly severe conditions and anticipating future problems, the government has developed a new conception of national tourism development by making adjustments and changes to policies, strategies and programs in the field of tourism . 
As national economic development is directed at the development of the people's economy, the development of quality tourism is not only aimed at increasing the country's foreign exchange, but also fulfilling the effect of equity, the empowerment of small and medium-sized communities.

Community-based tourism is considered important because: a) Can empower local people, in which they can share their experience and knowledge with others. Can create a new field of work for efforts to meet the needs of people's lives, b) Tourism benefits local people. Villagers and migrants work together to utilize the resources they have to attract visitors, c) Populist tourism as well as an effort to preserve the natural beauty, historical assets, preserve the

This paradigm shift must be balanced with reforms and the bureaucratic side of tourism, in order to compete and remain inherent in the global tourism business environment. The actors of tourism activities (in this case the government) are required and must understand the tourism business actors, know the scope and rules that exist and apply globally, and be able to apply the tactics and strategies needed to develop a tourist destination region in a sustainable and profitable. Based on the cultural capability of bureaucratic innovation that has been developed, the Local Government of Bali is expected to be able to answer this challenge.

To realize the bureaucratic cultural capability so as to be able to answer the demands of the global market, the policy of tourism development in Bali is directed to:

a. The development of bureaucratic resources, ie creative, dedicated, professional, bureaucratic establishment, entrepreneurial and forward-looking, through a well-planned and integrated mechanism. Bureaucratic competence is needed to improve bureaucracy in planning, implementation, evaluation and monitoing of tourism programs.

b. The development of bureaucratic resources must be carried out jointly with organizational strengthening which focuses on the management system to improve organizational performance, and institutional reforms that focus on the restructuring of functions and bureaucracy organizations that are efficient and oriented on quality improvement public service.

c. Taking into account the participation of the community as one of the variables of human resources in tourism development. Public participation is needed in tourism marketing and promotion activities, in addition to the private sector to replace the role of government who no longer act completely as the implementer of promotional activities, but only carry out the promotion of the image of national tourism (image promotion).

d. The diversification of tourism products originally based on natural and cultural resources, to be tourism products based on science and art, while ensuring a balance between human touch and technology so that its uniqueness and speciality have international standards that can penetrate the market that is very sensitive and care about aspects human life.

e. The development of tourism should be able to increase the empowerment of small and medium enterprises to accelerate the increase and distribution of local people's income by developing partnership and equality pattern between large, medium and small tourism businesses as the main actors of tourism development. Therefore, community-based tourism proliferation becomes a demand for tourism development for the foreseeable future.

f. Development of tourism based on the people, developed in the concept of PIR (Tourism Core People). This approach is expected to create tourism products that are characterized locally as basic capital and product marketing, on the other hand will be able to create socio-economic resilience and stability.

g. In order to strengthen the position and role of society in the development of national tourism, efforts are made to encourage the acceleration of structural change; requiring concrete steps that fundamentally allocate resources, institutional strengthening, and empowerment of human resources and community empowerment.

The development of cultural innovation capability within the bureaucratic body of Bali Government is expected to improve the performance of bureaucracy in the global market of tourism Reorientation of insight will be the way of thinking for bureaucracy to form new roles as:

Entrepreneur. With entrepreneurial professionalism, bureaucrats are able to see opportunities for the development of the tourism industry, the courage to take risks in exploiting the opportunities, and the ability to shift the allocation of low-productivity sources and activities to high-productivity activities that are open to marketing opportunities for the region which became a tourist destination. collaborate with the community and entrepreneurs to provide information and promotions on potential tourism that can be developed, tourist attractions and supporting services in the region. The established policy should be able to position the tourist destination area to be easily recognized and have more value and other DTW. The ability of managers to position DTW, will attract many potential travelers and markets that have been 
identified; create value that can attract many visitors through innovation; enhance cooperation among tourism actors; and coordinate in every initiative and action to be undertaken.

Mediator. Being closely related to the role of bureaucrats as entrepreneurs requires the ability to take decisions and necessary steps with reference to mission-driven professionalism, and not merely referring to rule-driven profesionelism. In many cases, government officials often have to take decisions and measures that simply refer to the mission to be achieved, namely the growth of the national economy and the acceleration of the structural transformation of society.

Facilitator. As a result of the increasing competition of tourism businesses and activities, bureaucrats are required to identify subjects with the potential to provide inputs and resources for the development of the tourism industry in a consistent and sustainable way. This ability should be followed up with linkage building, in anti-relationships and productive interactions with subjects that have the potential to contribute to the progress of the tourism industry in Bali.

For the private sector, bureaucrats act as facilitators to further develop tourist objects and attractions, through incentive research activities and incentives and active involvement of local communities in tourist destination areas in each development planning process. In order to ensure the success of the bureaucratic role, policy should be made to support the improvement of the quality and efficiency and tourism industry in Bali, and to protect the existing resources.

\section{CONCLUSIONS AND RECOMMENDATIONS}

The existence of a number of problems in the government bureaucracy which from year to year become public issues is an indication of the weak performance of bureaucratic reform. This is because the approach that has been applied to bureaucratic reform seems to have not yet touched a significant aspect of bureaucracy: the culture of government bureaucracy. This bureaucratic culture includes beliefs, values, and attitudes that allow the bureaucratic apparatus to move towards the expected goal. Experience in several countries, such as Iran and Malaysia, the bureaucratic value and culture approach proved to be a major approach in bureaucratic reform.

One of the most important aspects of bureaucratic culture for the success of bureaucratic reform is the culture of innovation. In the government bureaucracy in Indonesia, this innovation has not become the main value of bureaucratic culture. However, learning from the experience of innovation made by the Regional Government of Gorontalo Province, Jembrana Regency and Sragen Regency, the government bureaucracy in Indonesia basically has the potential to make various innovations in governance and development.

The process of globalization is characterized by increasingly bleak boundaries between countries and increasing competition between countries demands changes in the implementation of national tourism. Changes not only to policies, programs and programs in the field of tourism, but also the reform of bureaucracy and tourism. The development of bureaucratic innovation culture capabilities of the local government of Bali is expected to be able to print quality bureaucrats ready to face the challenges of globalization, supported by organizational strengthening of microstructures and institutional reforms on macro structures. Public service-oriented bureaucracy has implications for changing the role of the original bureaucrats as the main actors of development into mediators and facilitators.

\section{REFERENCES}

Caiden, G. 1969. Administrative Reform. Chicago: Aldine Publishing Co.

Dwiyanto, Agus. 2006. Reformasi Birokrasi Publik di Indonesia. Yogyakarta: Gadjah Mada University Press. Farazmand, Ali. 2002. Administrative Reform In Developing Nations, Praeger Publishers: C. Westport.

Kertajaya, Hermawan. 2000. Marketing Plus 2000 Siasat Memenangkan Persaingan Global. Jakarta: Gramedia Pustaka Utama

Lawson, B. dan Samson, D,. 2001. "Developing innovation capability in organizations: A dynamic capabilities approach". International Journal of Innovation Management, Vol. 5, No. 3, 377-400.

Peters, B. Guy. 2000. "Institutional Theory: Problems and Prospects". Department of Political Science, Institute for Advanced Studies (IHS), Stumpergasse 56, A-1060 Vienna.

Prasojo, Eko. 2006. "Reformasi Birokrasi di Indonesia: Beberapa Catatan Kritis". Jurnal Ilmu Administrasi dan Organisasi, Bisnis \& Birokrasi, Vol. 14, No. 1 (Januari). 
Salam, Abdul. 2002. "Globalisasi dan Kebijakan Pariwisata”. Dokumentasi Th. XIV No.7, Juli.

Shenkar, Odded. 2006. The Chinese Century: The Rising Chinese Economy and Its Impact on the Global Economy, The Balance of Power, and Your Job. Whartoon: School Publishing.

Sumadi, Ketut. 2002. "Pariwisata Budaya Bali Berbasis Kerakyatan Barkelanjutan”. Jurnal Manajemen Pariwisata. Vol. 1, No. 2, September, STIE Pariwisata Triatma Mulya, Bali.

Sunaryo, Bambang. 1993. "Pembangunan Pariwisata Berlanjut Berwawasan Lingkungan”, Makalah pada Kursus Nasional Peningkatan Kemampuan Penilaian AMDAL bidang Pariwisata, UGM, Yogyakarta, Oktober.

Terziovski, Mile. 2007. Building Innovation Capability in Organizations. London: Imperial College Press 